\title{
IMPLEMENTASI ALGORITMA STOCHASTIC HILL CLIMBING PADA PERMAINAN MASTERMIND
}

\author{
Ruby Vidian Hartanto, Joko Purwadi, Gunawan Santosa \\ Program Studi Teknik Informatika Fakultas Teknik \\ Universitas Kristen Duta Wacana Yogyakarta \\ Email: jokop@ukdw.ac.id, gunawan@ukdw.ac.id
}

\begin{abstract}
Abstrak:
Artikel ini membahas tentang implementasi algoritma Stochastic Hill Climbing (SHC) pada permainan Mastermind. Mastermind adalah salah satu jenis permainan papan yang dimainkan oleh dua orang pemain, dimana satu pemain berperan menyusun sebuah kombinasi 4 warna dari 6 buah warna yang tersedia. Sedangkan pemain lainnya bertugas menebak kombinasi warna yang dipilih oleh pemain pertama. Pemain pertama akan memberikan feedback kepada pemain kedua berdasarkan tebakan pemain kedua. Permasalahan yang dihadapi adalah bagaimana mencari langkah selanjutnya untuk memaksimalkan kemenangan.

Sistem yang dibangun untuk pencarian solusi menggunakan pendekatan algoritma Stochastic Hill Climbing. Pecarian dimulai dengan komputer memasukkan tebakan awal yang disebut CFG pada langkah pertama. Kemudian sistem mendapatkan feedback berdasarkan tebakan tersebut. Dari feedback tersebut sistem menentukan Tebakan Potensial yang akan digunakan untuk langkah berikutnya. Tebakan Potensial tersebut juga akan mendapatkan feedback, kemudian nilai heurstik dari CFG dan Tebakana Potensial akan dibandingkan, jika nilai heuristik CFG lebih kecil dari Tebakan Potensial, maka Tebakan Potensial tersebut akan dianggap sebagai CFG baru. Sebaliknya, jika nilai heuristik CFG lebih baik dari Tebakan Potensial, tentukan Tebakan Potensial berdasar CFG yang lama. Proses akan berlanjut hingga sistem mampu menebak Pola Rahasia.
\end{abstract}

Kata Kunci : heuristik, algoritma Stochastic Hill Climbing, Mastermind, kecerdasan buatan.

\section{Pendahuluan}

Game-game yang dibuat sekarang ini sebagian besar sudah mengimplementasikan Al (Artificial Intelligence) atau kecerdasan buatan. Dengan penerapan Al ini memungkinkan para pengguna sistem dapat bermain sendiri melawan sistem komputer yang mengimplementasikan 
Al tanpa perlu harus menunggu orang lain. Salah satu jenis game yang menggunakan Al adalah Mastermind. Pada penelitian ini, diterapkan algoritma Stochastic Hill Climbing untuk sebagai cara komputer untuk menemukan solusi dari permasalahan permainan mastermind.

\section{Landasan Teori}

\subsection{Kecerdasan Buatan (Artificial Intelegence)}

Artificial Intelligence adalah sistem yang mempelajari konsep, dapat berpikir dan menarik kesimpulan dari suatu masalah, dapat mengerti bahasa dan memahami pemandangan visual, serta sistem yang melakukan tugas-tugas lain yang membutuhkan kecerdasan manusia (Patterson, D. W., 1990, halaman 1).

Sistem yang menggunakan kecerdasan buatan, memiliki input berupa masalah dan menghasilkan output berupa solusi dari masalah yang diinputkan. Untuk dapat menghasilkan solusi, sistem harus dilengkapi dengan sekumpulan pengetahuan yang ada pada basis pengetahuan, selain itu sistem juga harus memiliki motor inferensi (inference engine) agar mampu mengambil keputusan berdasarkan fakta atau pengetahuan (Gambar 1).

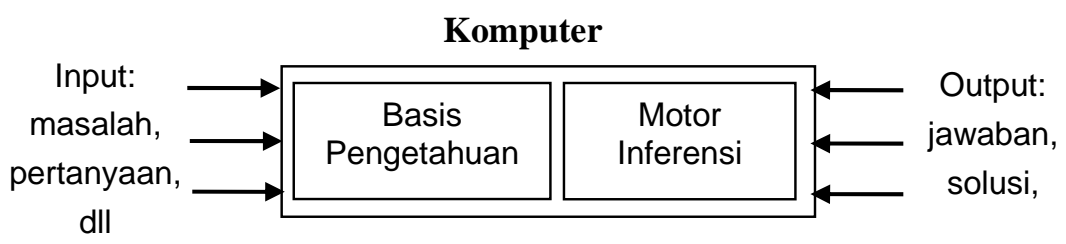

Gambar 1. Penerapan Konsep Kecerdasan Buatan di Komputer Dikutip dari: Kusumadewi, S.,2003, halaman 3.

\subsection{Algoritma Stochastic Hill Climbing}

Algoritma SHC merupakan pengembangan dari algoritma Hill Climbing. Stochastic Hill Climbing memilih nilai yang digunakan secara acak berdasarkan nilai probabilitas yang muncul. Nilai probabilitas yang digunakan untuk memilih simpul berikutnya bisa berbeda berdasarkan kecuraman dari pergerakan nilai yang menuju keatas (Russell, S., Norvig, P.,1995, halaman 111).

Pada permainan Mastermind, berikut adalah urutan dari algoritma SHC (Temporel, A., Kovacs, T., 2003).

- Tentukan tebakan pertama, tebakan ini disebut Current Favourite Guess(CFG).

- Dari CFG yang telah kita masukkan, ditentukan kode baru lagi dengan metode sebagai berikut : 
Langkah 1:

Jumlah warna kolom yang tetap digunakan dari tebakan sebelumnya/CFG bergantung pada angka pertama dalam kurung nilai(nilai tebakan yang tepat pada posisi yang tepat). Misalkan feedback yang diterima: [1,2], maka jumlah kolom yang tetap digunakan hanya 1 saja.

Langkah 2:

Kolom yang dipindahkan bergantung pada angka ke dua dalam kurung nilai(nilai tebakan yang tepat tetapi pada posisi yang salah). Misalkan feedback yang diterima: $[1,2]$, maka jumlah kolom yang dipindah lokasinya adalah 2 .

Langkah 3:

Kolom terakhir yang belum dioperasikan diberi nilai baru yang tidak muncul pada kolom-kolom sebelumnya. Pemberian warna pada kolom yang masih kosong dilakukan secara acak.

- Jika kode baru tidak konsisten terhadap semua tebakan sebelumnya, kembali ke langkah 2. tetapi jika kode baru telah konsisten, gunakan kode baru sebagai tebakan baru.

- Jika tebakan menghasilkan nilai [0,0], hilangkan semua warna yang ada pada tebakan tersebut. Tentukan kombinasi warna yang baru yang konsisten dengan semua nilai tebakan sebelumnya. Buat kombinasi baru ini sebagai CFG baru dan masukkan ke dalam kolom tebakan.

- Jika nilai tebakan yang dimasukkan sama dengan atau lebih baik dari nilai $C F G$ menurut heuristik pada tabel kemungkinan feedback, tebakan dianggap sebagai CFG baru dan tentukan nilai baru sebagai nilai yang terbaik.

- Jika tebakan belum menghasilkan feedback bernilai [4, 0] ulangi langkah ke-3. Untuk nilai Heuristik feedback dapat dilihat pada tabel 1.

- Selesai 
Tabel 1. Nilai Heuristik Feedback

\begin{tabular}{|c|c|}
\hline No. & Feedback \\
\hline 0 & {$[0,0]$} \\
\hline 1 & {$[0,1]$} \\
\hline 2 & {$[1,0]$} \\
\hline 3 & {$[0,2]$} \\
\hline 4 & {$[1,1]$} \\
\hline 5 & {$[2,0]$} \\
\hline 6 & {$[0,3]$} \\
\hline 7 & {$[1,2]$} \\
\hline 8 & {$[1,2]$} \\
\hline 9 & {$[3,0]$} \\
\hline 10 & {$[0,4]$} \\
\hline 11 & {$[1,3]$} \\
\hline 12 & {$[2,2]$} \\
\hline 13 & {$[4,0]$} \\
\hline
\end{tabular}

\section{Hasil Implementasi}

Pada bagian ini disajikan hasil implementasi algoritma SHC untuk menyelesaikan permainan Mastermind. Tampilan utama dari sistem ini adalah:

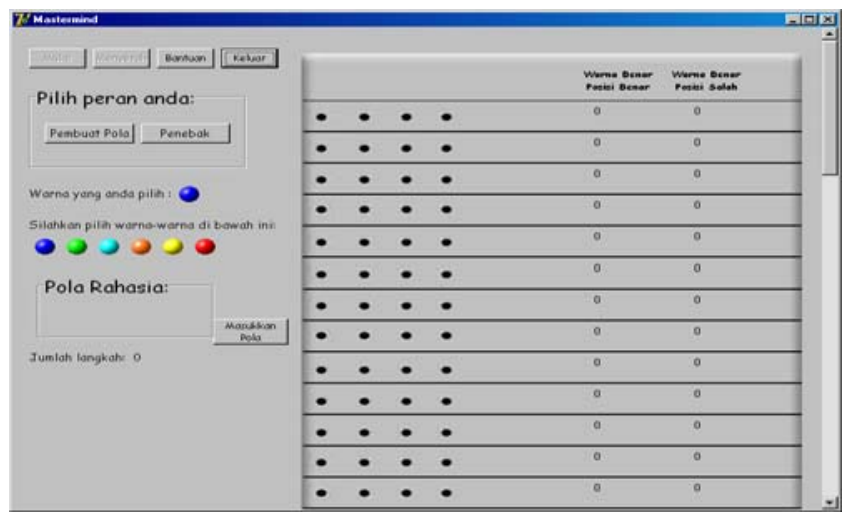

Gambar 2. Form Utama Permainan Mastermind

Gambar 2 menunjukkan tampilan awal Form Utama Permainan Mastermind. Permainan dimulai melalui pemilihan peran oleh user, apakah sebagai Penebak dengan menekan tombol Penebak, atau sebagai Pembuat Pola dengan menekan tombol Pembuat Pola. Ketika user memilih peran sebagai penebak, sistem menentukan Pola Rahasia secara random. Pola Rahasia terletak di GroupBox Pola Rahasia dengan kondisi tidak terlihat. Pola 
Rahasia akan muncul dengan 3 kondisi, yang pertama jika user berhasil menebak Pola Rahasia. Yang kedua, jika user menekan tombol Menyerah, dan membiarkan sistem memunculkan Pola Rahasia. Kondisi terakhir, jika user kalah, maka Pola Rahasia akan muncul.

Sistem telah menyediakan 6 warna yang digunakan dalam permainan. Warna yang dipilih user nampak pada baris warna yang dipilih atau di atas barisan warna. Setelah user memilih warna yang akan digunakan sebagai tebakan, berikutnya user meng-klik pada kolom tebakan yang telah disediakan. Kolom tebakan terisi sesuai warna yang telah kita pilih, sesuai dengan baris warna pilihan. Jika user telah mengisi semua kolom tebakan, berikutnya user mengklik tombol OK yang terletak pada sebelah kolom terakhir. Berdasarkan tebakan user, maka sistem akan memberikan feedback, sebagai acuan untuk user dalam memilih kombinasi pada langkah berikutnya. Hingga langkah ke 20 user belum berhasil menebak Pola Rahasia, maka user dinyatakan kalah, jika sebelum langkah ke-20 user berhasil menebak Pola Rahasia maka user dinyatakan menang. Ketika user meng-klik tombol Menyerah, menandakan bahwa user telah menyerah dalam menebak Pola Rahasia, sehingga user dinyatakan kalah. Untuk kembali bermain, klik tombol Mulai yang terletak di bagian atas.

Saat user berperan sebagai Pembuat Pola, user wajib menentukan pola yang akan ditebak oleh sistem. Berikutnya sistem akan menebak pola dengan menggunakan metode Stochastic Hill Climbing. Jika sampai langkah maksimal sistem tidak berhasil menemukan Pola Rahasia, maka user keluar sebagai pemenang. Namun, sebelum langkah maksimal sistem berhasil menebak Pola Rahasia, maka sistemlah yang keluar sebagai pemenang.

Dalam sistem yang dikembangkan, proses algoritma SHC dibuat dalam beberapa prosedur. Proses diawali dengan prosedure penentuan Tebakan Awal (CFG), dilanjutakan prosedur Pengecekan Heuristic, prosedur penentuan Tebakan Potensial dan prosedur penghapusan warna. Prosedur-prosedur tersebut akan bekerja saat user selesai menentukan Pola Rahasia dan menekan tombol Masukkan Pola.

\section{Analisis Hasil Penelitian}

Pada sub bab ini akan diuraikan analisis dari implementasi algoritma SHC untuk menyelesaikan permainan Mastermind. 


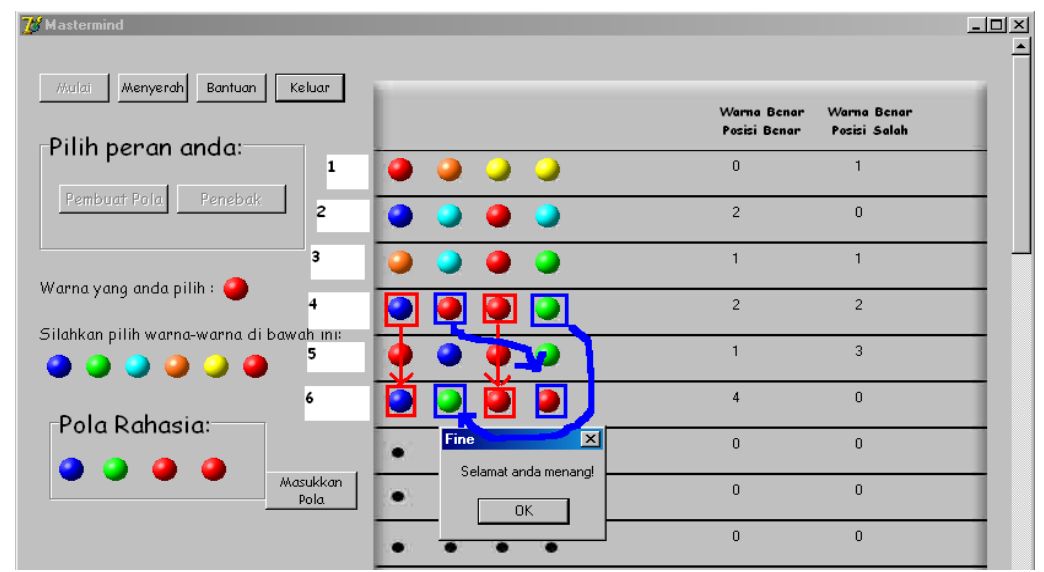

Gambar 3. Penyelesaian Permainan Mastermind

Langkah 1, sistem memasukkan tebakan pertama sebagai CFG dengan kombinasi Merah-Oranye-Kuning-Kuning, feedback langkah pertama adalah [0,1], nilai heuristik 1 . Langkah 2, sistem memasukkan tebakan potensial dengan kombinasi Biru-Biru Muda-MerahBiru Muda, dengan warna Merah diubah posisinya ke kolom 3. Feedback langkah ke-2 adalah $[2,0]$, nilai heuristik 5. Karena nilai heuristik langkah 2 lebih besar dari langkah 1 , maka kombinasi warna langkah 2 dianggap sebagai CFG. Langkah 3, sistem memasukkan tebakan potensial dengan kombinasi Oranye-Biru Muda-Merah-Hijau, dengan warna Merah dan Biru Muda pertama tetap pada posisinya. Feedback langkah ke-3 adalah [1,1], nilai heuristik 4. Karena nilai heuristik langkah 3 lebih kecil dari langkah 2, maka CFG tidak berubah.

Langkah 4, sistem memasukkan tebakan potensial dengan kombinasi Biru-MerahMerah-Hijau, dengan warna Merah dan Biru tetap pada posisinya. Feedback langkah 4 [2,2], nilai heuristik 12. Karena nilai heuristik langkah 4 lebih besar dari langkah 3, maka kombinasi langkah 4 dianggap sebagai CFG. Langkah 5, sistem memasukkan tebakan potensial MerahBiru-Merah-Hijau, dengan warna Hijau dan Merah ke-2 tetap pada posisinya, warna Biru digeser ke kolom 2 dan warna Merah pertama di geser ke kolom 1. Feedback langkah 5 adalah [1,3], nilai heuristik 11. Karena nilai heuristik langkah 5 lebih kecil dari langkah 4, maka CFG tidak berubah. Langkah 6, sistem memasukkan tebakan potensial dengan kombinasi BiruHijau-Merah-Merah, dengan warna Merah ke-2 dan warna biru pada langkah 4 tetap pada posisinya, warna Merah pertama pindah ke kolom 4 dan warna Hijau pindah ke kolom 2. Feedback langkah 6 adalah [4,0], nilai heuristik 13. Karena Pola Rahasia telah berhasil ditebak, maka permainan berakhir, sistem dinyatakan sebagai pemenang. Hal ini menunjukkan bahwa algoritma SHC mampu menyelesaikan permainan Mastermind.

Namun ada kalanya algoritma ini tidak mempu menyelesaikan permainan sampai langkah maksimal yang telah ditentukan. Pada beberapa kasus seperti yang tertera pada Tabel 2 terlihat bahwa SHC menyelesaikan permainan hingga 49 langkah, padahal jumlah maksimal tebakan adalah 20 langkah. Hal ini disebabkan fungsi acak yang digunakan untuk menentukan warna yang akan mengisi kolom yang masih kosong. 
Tabel 2. Penyelesaian Permainan Lebih Dari 30 Langkah

\begin{tabular}{|c|l|c|}
\hline No Ujicoba & \multicolumn{1}{|c|}{ Pola Rahasia } & Jumlah Langkah \\
\hline 1 & Biru-Hijau-Kuning-Merah & 32 \\
\hline 2 & Biru-Hijau-Oranye-Kuning & 31 \\
\hline 3 & Hijau-BiruMuda-Biru-Oranye & 49 \\
\hline 4 & Hijau-Hijau-Merah-Oranye & 35 \\
\hline 5 & Biru-Merah-Kuning-BiruMuda & 32 \\
\hline
\end{tabular}

Selain itu juga dilakukan analisa banyaknya jenis warna untuk kombinasi Pola Rahasia terhadap jumlah langkah dalam menyelesaikan permianan Mastermind. Mengacu pada Tabel 3 , semakin banyak jenis warna yang digunakan, jumlah langkah yang digunakan untuk menyelesaikan permainan. juga relatif lebih banyak.

Tabel 3. Hasil perhitungan nilai $g(n), h(n), f(n)$ dan $c(n)$ untuk setiap cabang Kesiman dan Tonja

\begin{tabular}{|c|c|c|}
\hline Banyak Jenis Warna & Jumlah Percobaan & Rata-rata Jumlah Langkah \\
\hline 1 & 20 & 5,5 \\
\hline 2 & 20 & 10,2 \\
\hline 3 & 20 & 16,6 \\
\hline 4 & 20 & 23,6 \\
\hline
\end{tabular}

\section{Kesimpulan}

Dari hasil penelitian yang telah dilakukan, dapat disimpulkan beberapa hal mengenai Algoritma Stochastic Hill Climbing pada permainan Mastermind yaitu :

1. Metode Stochastic Hill Climbing dengan fungsi heuristic dapat digunakan untuk menyelesaikan permainan Mastermind.

2. Penerapan Metode Stochastic Hill Climbing mampu bekerja cukup baik. Namun pada beberapa ujicoba diperlukan langkah penyelesaian yang lebih banyak dari batas langkah maksimal untuk menyelesaikan permainan Mastermind.

3. Berdasarkan analisis, semakin banyak jenis warna yang digunakan sebagai Pola Rahasia, lebih banyak langkah yang diperlukan untuk menyelesaikan permainan Mastemind. Semakin sedikit jumlah warna yang dikombinasikan, jumlah langkah yang diperlukan untuk menyelesaikan permainan relatif lebih sedikit.

\section{Daftar Pustaka}

[1] Faris , F. (April 15, 2007). Mastermind game. Diambil dari http://www.planet-sourcecode.com/vb/scripts/ShowZip.asp?IngWld=7\&IngCodeld=925\&strZipAccessCode=tp\%2FM 9250122, 
[2] Kusumadewi, S. (2003). Artificial intelligence: Teknik dan penerapannya. Graha ilmu, Yogyakarta.

[3] Luger, G.F., Stubblefield, W.A. (1989). Artificial intelligence and the design of expert system. The Benjamin, Cummings.

[4] Nelson, T. (March 9, 2000). Break the hidden code. Diambil dari http://www.tnelson.demon.co.uk/mastermind/history.html,

[5] Patterson, D. W. (1990). Introduction to artificial intelligence and expert system. Prentice hall, Inc.

[6] Pranata, A. (2002). Pemrograman borland delphi 6 edisi 4, Penerbit Andi, Yogyakarta.

[7] Russell, S., Norvig, P. (1995). Artificial intelligence: A modern approach. Prentice Hall, Inc.

[8] Temporel, A., Kovacs, T. (September 2003). A heuristic hill climbing algorithm for mastermind. Proceedings of the 2003 UK Workshop on Computational Intelligence (UKCl03). Diambil dari http://www.cs.bris.ac.uk/Publications/Papers/2000067.pdf.

[9] Wahana Komputer. (2003). Pemrograman borland delphi 6.0. Penerbit Andi, Yogyakarta. 